\title{
Drying Characteristics of Fenugreek and Its Computer Simulation for Automatic Operation
}

\author{
Ramandeep Kaur ${ }^{1}$, Mahesh Kumar ${ }^{1}$, O.P. Gupta ${ }^{1}$, \\ Sukreeti Sharma $^{2 *}$ and Satish Kumar ${ }^{1}$ \\ ${ }^{1}$ Department of Processing and Food Engineering, Punjab Agricultural University, \\ Ludhiana -141 004, Punjab, India \\ ${ }^{2}$ ICAR-Indian Institute of Millets Research, Hyderabad- 500 030, India
}

*Corresponding author

\section{A B S T R A C T}

\section{Keywords}

Fenugreek, Tray dryer, Drying models,

Diffusivity, Quality

parameters, Programming

Article Info

Accepted:

26 February 2018

Available Online:

10 March 2018
A Computer program in 'Visual Basic' language was developed for fenugreek to rapidly determine the drying time and drying rate for a particular temperature and moisture content to minimize the operational problems. The drying was carried out in a tray dryer (Kilburn make Laboratory tray dryer) with heated air at a temperature of $50,60,70{ }^{\circ} \mathrm{C}$ and its combination. The time to reach equilibrium moisture content decreased with increase in drying air temperature $\left(50^{\circ}-70^{\circ} \mathrm{C}\right)$. The logarithmic model showed the best fit to the data with high values of coefficient of determination $\mathrm{R}^{2}(0.994-0.998)$ and low $\chi 2$, MBE and RMSE values. Results showed, a maximum value of $4.49,150.4 \mathrm{mg} / 100 \mathrm{~g}$ and $1360 \mathrm{mg}$ $\mathrm{GAE} / 100 \mathrm{~g}$ at $70{ }^{\circ} \mathrm{C}$ for rehydration ratio, ascorbic acid, and polyphenols content respectively. However, optimum tray drying at $61{ }^{0} \mathrm{C}$ with $0.8 \mathrm{~g} / \mathrm{cm}^{3}$ loading density shows maximum retention of the same with minimum change in color and shrinkage ratio.

\section{Introduction}

Fenugreek (Trigonella foenumgraecum L.) is the member of Leguminosae family. It is widely cultivated in warm temperate and tropical regions in the Mediterranean, Europe, and Asia. The major seed producing countries are India, Ethiopia, Egypt, and Turkey. In India, the seeds are used in curries, dyes, and medicines and young seedlings are often eaten as a vegetable. In Europe and North America, the seed is used for its pharmaceutical qualities, as a spice, as an imitation maple, vanilla, rum or butterscotch flavoring, and in health food. Fenugreek leaves are rich in vitamin $\mathrm{C}$, protein and minerals. It has some medicinal values. Primary among them includes its ability to lower sugar levels in the blood of diabetics. Other includes its digestive properties and usages as emollient. India is the largest producer and exporter of fenugreek in the world with 113 MMT production in 93000 ha area. Over $90 \%$ of the Indian production is concentrated in Rajasthan and Gujarat of which around $33 \%-34 \%$ is exported. (Anon 2013)

Fenugreek is highly perishable in nature having a very short shelf life. During the peak period, most of the crop is lost /wasted due to 
lack of post-harvest techniques. Different food processing methods are used with a major goal to convert perishable commodities into stable products that can be stored for extended periods, thereby reducing losses and making them available at the time of shortage and offseason use and for places which are far away from the production site. Organized and unorganized Indian processing industries presently consume only 4 percent of the total production in the country as compared to about 30-67 \% in developed European countries (Rana and Pandey, 2007). Drying is one of the most common food preservation techniques.

The quality of dehydrated food product is influenced by drying conditions such as temperature, airflow and relative humidity (Gorinicki and Kaleta, 2007). Negi and Roy (2001) reported that maximum loss of $\beta$ carotene and ascorbic acid were observed in solar drying as compared to cabinet drying. The loss of chlorophyll was also higher in solar drying, which causes an increase in the browning of dehydrated green leaves during storage. Naidu et al., 2012 investigated for efficient dehydration of fenugreek (Trigonella foenum-graecum) greens with different drying methods hot air (HA, $\left.40^{\circ} \mathrm{C}, 58-63 \% \mathrm{RH}\right)$, low humidity air (LHA, $40^{\circ} \mathrm{C}$ and $28-30 \% \mathrm{RH}$ ) and radiofrequency $\left(\mathrm{RF}, 40^{\circ} \mathrm{C}, 56-60 \% \mathrm{RH}\right)$ were explored for efficient drying of fenugreek greens. The time required for drying with LHA and RF was less (27\%), as compared to HA drying. LHA-dried fenugreek had superior green color and a more porous and uniform structure than those obtained from RF and HA drying. Dehydrated fenugreek greens showed good consumer acceptance as wellas shelf life. Pande et al., (2000) carried out studies on drying of fenugreek and coriander leaves at different temperatures using forced circulation air dryer and found that dried samples were acceptable to the respondents.
Although there are several studies on dehydration of fenugreek greens was done. But the effect of different drying temperature on thin layer drying kinetics and optimized quality parameters have not been studied with a controlled computer program. Hence, the objective of this study was:-

To evaluate the effect of different drying temperature on drying kinetics and development of the automated program.

To evaluate the suitability of selected thinlayer drying models and effect diffusivity for drying.

Optimization of physicochemical characteristics (color, rehydration ratio, shrinkage ratio, ascorbic acid and polyphenols content).

\section{Materials and Methods}

The experiment to accomplish the desired objectives was performed in the laboratory of the Department of Processing and Food Engineering and Punjab Horticultural, Punjab Agricultural University, Ludhiana. Fenugreek was procured from local market. The fresh fenugreek leaves were visually sorted, trimmed, washed. The mash was then dried in a mechanical tray dryer at different temperatures; to evaluate the effect on the drying behavior. Vital physiochemical characteristics viz. moisture content, rehydration ratio, shrinkage ratio, color, ascorbic acid and polyphenols content of fresh and dried fenugreek were also estimated.

\section{Processing and pretreatments}

Fresh Fenugreek leaves were blanched in hot boiling water at $100^{\circ} \mathrm{C}$ for $1 \mathrm{~min}$. Then blanched fenugreek leaves were dipped in cold water. Leaves were spread over drying trays and loaded into the tray dryer for drying. 


\section{Drying of fenugreek leaves}

The experimental set-up for mechanical tray drying of fenugreek leaves consisted of Kilburn make Laboratory tray dryer with the maximum attainable temperature of $200^{\circ} \mathrm{C}$. Dryer consists of the centrifugal blower which circulates air inside the dryer with an air velocity of $0.8 \mathrm{~m} / \mathrm{sec}$. The dimension of tray drier was $81.7 \mathrm{X} 41 \mathrm{~cm}$ in which the blower is powered by $0.25 \mathrm{HP}$, three phase $440 \mathrm{~V}$ electric motor with a direct online starter. The convective dehydration was carried out at different temperatures $\left(50,60\right.$ and $\left.70^{\circ} \mathrm{C}\right)$.

The samples were convectively dehydrated in hot air tray drier till weight loss becomes constant. The loss in weight was measured at a regular interval of 30 min during drying by weighing balance Excel $\mathrm{BH}$ - Series $(5 \mathrm{~kg}$ capacity with least count of $0.01 \mathrm{~g}$ ). The dried product was cooled to the room temperature then kept in polythene. Drying tests were replicated three times at each inlet air temperature and an average is reported.

\section{Drying analysis and evaluation of thin layer drying models}

Drying curves were fitted with three thin layer drying models Newton, Henderson and Pabis and the Logarithmic models were used to describe the drying kinetics of sample. These are listed in Table 1. Drying curves were fitted to the experimental data using these moisture ratio equations. $\mathrm{MR}$ is the moisture ratio defined as $\mathrm{M} / \mathrm{M} 0: \mathrm{M}$ is the moisture content at time $t$ and $\mathrm{M} 0$ is the initial moisture content, dry basis. Moisture ratio (MR) as M/M0 was used instead of (M-Me/ M0-Me) as used by many authors (Diamante and Munro, 1993; Yaldiz et al., 2001; Pokharkar and Parsad, 2002).

M.R. $=$ Moisture ratio $=\frac{\frac{M-M e}{M o-M e}}{(1)}$
Where,

$\mathrm{M}, \mathrm{Me}$ and Mo are moisture contents (db) at any time ' $\mathrm{t}$ ', at equilibrium and at time $\mathrm{t}=0$, respectively. a and $\mathrm{c}$ are drying coefficients and $\mathrm{k}$ is drying constants in these models.

\section{Adequacy of fit of various empirical models}

Modeling the drying behavior of fenugreek products requires the statistical methods of regression and correlation analysis. Linear and nonlinear regression models are important tools to find the relationship between different variables, especially for which no established empirical relationship exists. Regression analysis was conducted to fit the mathematical models by the statistical package for social sciences (SPSS version 11.5). The determination coefficient $\left(\mathrm{R}^{2}\right)$ and plots of residuals were the primary criteria for selecting the best equation to define the drying curves. In addition to $\mathrm{R}^{2}$, the goodness of fit was determined by various statistical parameters such as reduced chi-square $\left(\chi^{2}\right)$, mean bias error (MBE) and root mean square error (RMSE) were defined by the equations 2.1 to 2.4 (Gomez and Gomez, 1983).

$$
R^{2}=\frac{\sum_{i=1}^{n}\left(M R_{i}-M R_{p r e . i}\right) \cdot \sum_{i=1}^{n}\left(M R_{i}-M R_{\text {exp }, i}\right)}{\sqrt{\left[\sum_{i=1}^{n}\left(M R_{i}-M R_{p r e . i}\right)^{2}\right] \cdot\left[\sum_{i=1}^{n}\left(M R_{i}-M R_{\text {exp. }, i}\right)^{2}\right]}}
$$

$\chi^{2}=\frac{\sum_{i=1}^{n}\left(M R_{\text {ex }, i}-M R_{p r e, i}\right)^{2}}{N-n}$

$M B E=\frac{1}{N} \sum_{i=1}^{N}\left(M R_{p r e, i}-M R_{\mathrm{exp}, i}\right)$

$R M B E=\left[\frac{1}{N} \sum_{i=1}^{N}\left(M R_{p r e, i}-M R_{\exp , i}\right)^{2}\right]^{\frac{1}{2}}$ 
Where, $M R_{\text {exp, } i \text { and } M R_{\text {pre, } i} \text { are experimental }}$ and predicted dimensionless moisture ratios, respectively, $N$ is a number of observations and $n$ is a number of constants.

The best model describing the drying characteristics of samples was chosen as the one with the highest coefficient of determination, the least mean relative error, reduced chi-square and RMSE (Sarsavadia et al., 1999; Madamba, 2003; Sacilik et al., 2006).

\section{Effective moisture diffusivity during drying}

Fick's diffusion equation for objects with slab geometry is used for calculation of effective diffusivity. Fick's diffusion equation is the only physical mechanism to transfer the water to the surface (Dadali et al., 2007; Dincer and Dost, 1995; Wang et al., 2007). When the plot of the logarithm of moisture ratio (ln MR) versus drying time is linear, the moisture diffusivity assumes an independent function of moisture content. The equation is expressed as (Maskan et al., 2002)

$M R=\frac{M_{t}}{M_{0}}=\frac{8}{\pi^{2}} \exp \left[-\frac{D_{e f f} \pi^{2} . \mathrm{t}}{4 \mathrm{~L}^{2}}\right]$

Where MR is the dimensionless moisture ratio, $D_{\text {eff }}$ is the effective moisture diffusivity in $\mathrm{m}^{2} / \mathrm{s}, \mathrm{t}$ is the time taken during drying in seconds and $\mathrm{L}$ is half of the slab thickness in meters. It is further simplified to straight line equation

$\operatorname{In}(M R)=\operatorname{In}\left(\frac{8}{\pi^{2}}\right)-\left(\frac{D_{e f f} \cdot \pi^{2}}{4 L^{2}} \cdot t\right)$

The effective moisture diffusivity was calculated using the method of slopes. Linear regression analysis was employed to obtain values of diffusion coefficients for different drying conditions from the slope of the straight lines obtained.

\section{Physico-chemical analysis}

\section{Analysis of color change}

The color of the fresh fenugreek and dried powder was determined by using Hunter Lab Miniscan XE Plus Colorimeter. The calibrated colorimeter is used for measuring color value $\left(\mathrm{L}^{*}, \mathrm{a}^{*}\right.$ and $\left.\mathrm{b}^{*}\right)$ at different points. $\mathrm{L}^{*}$ represents the lightness index, $\mathrm{a}^{*}$ represent red green and $b^{*}$ represent yellow-blue color component. The average of each sample was calculated.

Colour change $\Delta E=\sqrt{(}\left(\Delta L^{2}+\Delta a^{2}+\Delta b^{2}\right)$

Where $\Delta \mathrm{L}, \Delta \mathrm{a}$ and $\Delta \mathrm{b}$ are deviations from 'L','a' and 'b' values of fresh sample.

$\Delta \mathrm{L}=\mathrm{L}$ dried sample $-\mathrm{L}$ fresh sample; $\Delta \mathrm{a}=\mathrm{a}$ dried sample- a fresh sample; $\Delta \mathrm{b}=\mathrm{b}$ dried sample $-\mathrm{b}$ fresh samples.

\section{Shrinkage ratio}

The shrinkage ratio of dried sample was measured by using toluene displacement method. Shrinkage ratio was calculated as the percentage change from the initial apparent volume (Mohsenin, 1986).

Shrinkage ratio $=\frac{V_{r}}{V_{o}}$

Where, $\mathrm{V}_{\mathrm{r}}=$ Volume displaced by rehydrated sample, $\mathrm{ml}$ and $\mathrm{V}_{0}=$ Volume displaced by fresh sample, $\mathrm{ml}$

\section{Rehydration ratio}

The rehydration test is significant when the dried sample needs to be reconstituted before consumption. It is expected that the dried 
product on reconstitution is close to the fresh material in terms of color and flavor. Reconstitution quality was evaluated by soaking known weight (5-10 g) of each sample in sufficient volume of water in a glass beaker (approximately 30 times the weight of sample) at $95^{\circ} \mathrm{C}$ for 20 minutes. After soaking, the excess water was removed with the help of filter paper and samples were weighed. The weighing of sample was done until they attain constant weight change nearly about 3 hours. In order to minimize the leaching losses, water bath was used for maintaining the set temperature (Ranganna, 1986). Rehydration ratio (RR) of the samples and was computed as follows:

Rehydration ratio $=\frac{W_{r}}{W_{d}}$

Where, $\mathrm{W}_{\mathrm{r}}=$ Drained weight of rehydrated sample, $g$ and $\mathrm{W}_{\mathrm{d}}=$ Weight of dried sample used for rehydration, $g$

\section{Ascorbic acid}

The ascorbic acid content was analyzed by using AOAC (2006) method. Preparation of chemicals was done by mixing $40 \mathrm{ml}$ of acetic acid and $15 \mathrm{~g}$ of metaphosphoric acid were dissolved in $450 \mathrm{ml}$ of distilled water for making MP-AA solution. For dye solution took $52 \mathrm{mg}$ of 2,6 dichlorophenol indophenols and $42 \mathrm{mg}$ of sodium bicarbonate in $200 \mathrm{ml}$ of dw and solution was filtered. For standardization, $20 \mathrm{mg}$ of vitamin $\mathrm{C}$ was dissolved in $100 \mathrm{ml}$ of MP-AA solution. Test was performed by taking $1 \mathrm{~g}$ of crushed sample using MP-AA solution and then filter. $5 \mathrm{ml}$ extract was titrated against the dye. Volume of dye used to oxidize vitamin $\mathrm{C}$ in sample was noted.

Ascorbic acid content $(\mathrm{mg} / 100 \mathrm{~g})=$ $\frac{\text { TitervalueXD.F Xvolmade }}{\text { wit.of sampleXaliquat }} \times 100$
D.F $=$ Dye factor $=(0.5 /$ titer value $)$

\section{Estimation of polyphenols}

Total phenolic content was determined by Singleton et al., (1999) method. 1 gram sample was refluxed with $80 \%$ aqueous methanol for 3 hours at $40^{\circ} \mathrm{C}$ and residue was then further refluxed for 1 hour. After filtration of extracts, the final volume was made to $100 \mathrm{ml}$ with $80 \%$ aqueous methanol. For estimation of total phenol, $0.5 \mathrm{ml}$ of this extract was mixed with $5 \mathrm{ml}$ Folin-Ciocalteu reagent. After3 $\mathrm{min}, 4 \mathrm{ml}$ of saturated sodium carbonate solution was added. After standing for $30 \mathrm{~min}$ at room temperature, the absorbance was measured at $765 \mathrm{~nm}$. The values were reported as $\mathrm{mg}$ of Gallic acid equivalent (GAE) by reference to gallic acid standard curve. The results were expressed as milligrams of GAE per $100 \mathrm{ml}$.

Phenol conc. $\mathrm{mg} / 100 \mathrm{~g}$ GAE = Phenol value from graph $\times$ final volmade $\times 100$

wt of sample xaliquate

\section{Overall acceptability}

Overall acceptability was evaluated as an average of colour, appearance, taste is expressed in percentage. The average scores of all the 10 panelists were computed for different characteristics.

\section{Computer based program}

For making of computer based program fenugreek leaves were dried at different air temperature $\left(50,60\right.$ and $\left.70{ }^{\circ} \mathrm{C}\right)$. After every 30 min change in weight was analyzed. From this data change in moisture content, drying time and drying rate was calculated. With help of excel sheets values were plotted on graphs. From effect of moisture content on drying time and drying rate at different temperature 
program is developed in paradigm of information technology. Visual basic program a computer language is used for this purpose. The drying temperature and moisture content of crop was taken as data input option. The results of drying at different temperature and different moisture content were computed as drying time and drying rate output.

\section{Statistical analysis}

Drying kinetics, mathematical modeling was analysed with SPSS (version 11.5). An ANOVA study was performed using Design Expert (version 7.0) software for determining the effect of independent variable (temperature and loading density) on quality of the final product using significance level of $5 \%$.

\section{Results and Discussion}

\section{Characteristics of fresh fenugreek leaves}

Fresh fenugreek samples properties were analysed before drying. The moisture content of fresh fenugreek was 89 (\% wb) as shown in Table 2. Out of $5 \mathrm{~kg}$ of fenugreek samples $2200 \mathrm{~g}$ of clean trimmed fenugreek leaves was obtained. $250 \mathrm{~g}$ of dried fenugreek was recovered.

\section{Drying behavior of fenugreek}

\section{Influence of drying temperature}

Results of moisture content and drying rate during drying time, obtained in experiment for thin layer drying of fenugreek leaves were carried outat $50^{\circ} \mathrm{C}, 60^{\circ} \mathrm{C}$ and $70^{\circ} \mathrm{C}$ have been reported in Figure 1 and 2. As it can be observed that a constant rate drying period was not found in drying curves. These all curves flow falling rate period and smooth diffusion controlled drying behaviour under all different drying temperatures. An increase in the temperature accelerated the drying process resulted in a decrease in the drying time. Drying time $(540 \mathrm{~min})$ required for $50^{\circ} \mathrm{C}$ drying temperature is much higher than other temperatures. At drying temperature $70^{\circ} \mathrm{C}$ the total drying time reduced upto $38.88 \%$. There was significant difference in the drying time with different drying temperatures $(\mathrm{p}<0.05)$ as shown in Table 3 . The decrease in drying time increases the product quality. The results were generally in agreement with some literature studies on drying behaviour of various food products (Doymaz, 2006; Akpinar et al., 2003; Senadeera et al., 2003).

Change in drying rate means the $\mathrm{kg}$ of water removed from $\mathrm{kg}$ of bone dried weight. The changes in drying rates versus drying time are shown in Figure 2. The increased drying temperature causes an accelerated drying process. Drying process is controlled by internal diffusion of moisture within the product. It is apparent that drying rate increased with increase in drying temperature. With increase in drying time the drying rate decreased continuously due to decrease in moisture content which causes the decreased moisture migration and evaporation rate from the surface of the product. The highest values of drying rates were observed at $70^{\circ} \mathrm{C}$ at first $180 \mathrm{~min}$. After $180 \mathrm{~min}$ drying, drying rate was lower than $50^{\circ} \mathrm{C}$. With high moisture content and drying temperature increased the heat transfer potential between the air and fenugreek leaves. Gupta et al., (2011), Doymaz (2004) and Akpinar (2006) showed similar effect of air drying temperatures on drying rate.

\section{Evaluation of drying models}

In order to evaluate the performance of convective models, the values of statistical parameters for all the experiment runs were compared. These models coefficients and the results of statistical analyses are presented 
given in Table 4. Newton, Henderson and Pabis and Logarithmic models were fitted. All models gave higher coefficient of determination $\left(\mathrm{R}^{2}\right)$ values in range 0.979 0.997. These values indicate that all models satisfactorily describe the drying of fenugreek leaves. The best model among these three with highest $\mathrm{R}^{2}$ and lowest $\chi^{2}$, Mean Bias Error (MBE), Root Mean Square Error (RMSE) values were obtained in Logarithmic model. Maximum coefficient of determination was obtained at $70^{\circ} \mathrm{C}$ was 0.998 with least $\chi^{2}$ (0.0006), MBE (-0.0038) and lowest RMSE $(0.0002)$. The value of $\mathrm{k}$ increased with increase in temperature shows the fact that drying kinetics was temperature dependent (Table 4) for all drying models. Same results were observed by Rayaguru and Routray (2012), Gupta et al., (2011) and Doymaz (2006).

\section{Effective moisture diffusivity for drying process}

Drying method has pronounced effect on the drying rate and consequently it has effect on the diffusivity. The increase in temperature, the effective diffusivity increased due to the increase in vapor pressure inside the sample. Similar result was observed by Meisami-asl et $a l$. , (2010) for apple slices.

The values of effective diffusivity ( $\left.D_{\text {eff }}\right)$ increased in range of $3.84 \times 10^{-10}$ to $7.99 \times 10^{-}$ ${ }^{10}\left(\mathrm{~m}^{2} / \mathrm{s}\right)$ with increased drying temperature from $50^{\circ} \mathrm{C}$ to $70^{\circ} \mathrm{C}$ (Table 5). Naidu et al., (2012) described the increased diffusivity of fenugreek is indicator of lower resistance to mass transfer in the material being dried. Though values obtained are within the suitable range for food products $\left(10^{-12}\right.$ to $\left.10^{-6} \mathrm{~m}^{2} / \mathrm{sec}\right)$ reported in literature (Zogas et al., 1996 and Maskan et al., 2002). Moisture diffusivity during air drying had been found in lateral studies like in apricots, peach slices, tomatoes (Pala et al., 1996; Kingsly et al., 2007; Doymaz, 2007).

\section{Optimization of the drying process of fenugreek}

The experimental data of rehydration ratio (RR), shrinkage ratio (SR), colour changes, ascorbic acid, polyphenol content and overall acceptability of dried fenugreek leaves for each temperature $\left(50^{\circ} \mathrm{C}, 60^{\circ} \mathrm{C}\right.$ and $\left.70^{\circ} \mathrm{C}\right)$ and loading density $\left(0.4,0.6\right.$ and $\left.0.8 \mathrm{~g} / \mathrm{cm}^{3}\right)$ combination is presented in Table 6 . The response surface plots were generated for interactions of two variables (temperature and loading density) on the quality parameters of fenugreek.

\section{Rehydration ratio}

Rehydration ratio for fenugreek leaves varied in range of $3.63-4.49$ for drying air temperature $50-70^{\circ} \mathrm{C}$. The maximum rehydration ratio was observed at higher drying air temperature $70^{\circ} \mathrm{C}$ (Fig. 3). Higher temperatures improve rehydration ratio due to the effect of temperature on cell wall and tissue.

Galvez et al., (2008) observed that the maximum rehydration ratio was a function of the air temperature used during the drying process; absorbed water increased with an increase in air drying temperature. This was probably the result of the tissue collapse and cell damage produced by higher air temperatures, resulting in an increase in the rehydration ratio due to water retention in the spaces created by the damaged cells.

Final equation predicting Rehydration Ratio as affected by temperature and loading density is given below:

Rehydration ratio $=-1.61921+0.14420 *$ temperature $+1.49035^{*}$ loading density$0.048750 *$ temperature *loading density7.57895E-004* temperature ${ }^{2}+1.98026 *$ loading density ${ }^{2}$ 
Fig.1 Effect of moisture content $(\% \mathrm{db})$ on drying time at different drying temperature

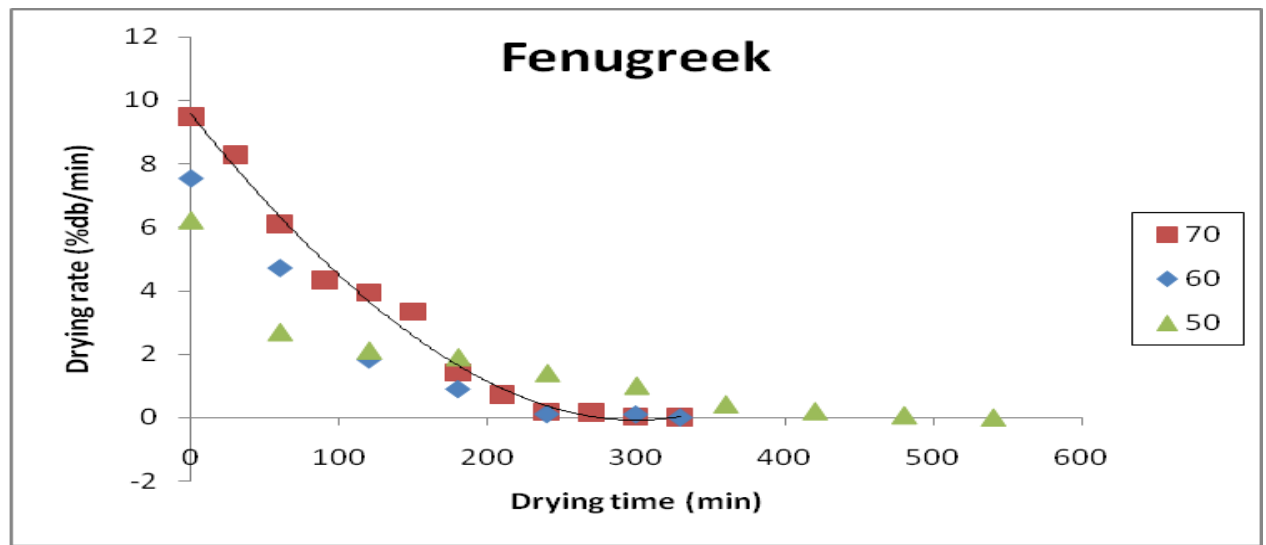

Fig.2 Effect of drying rate $(\% \mathrm{db} / \mathrm{min})$ on drying time at different drying temperature

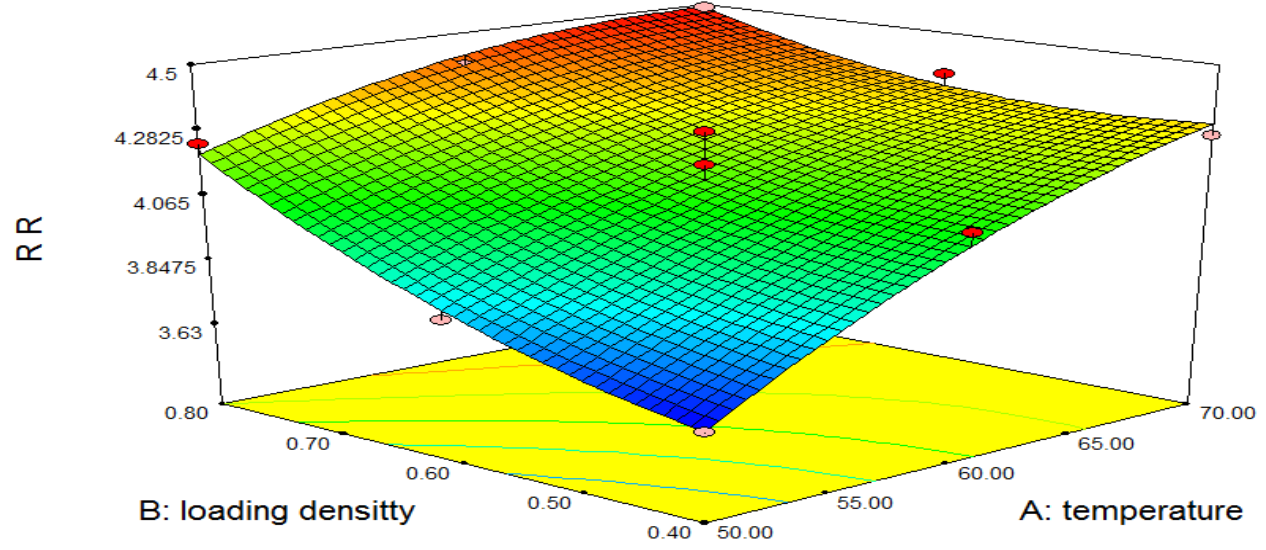

Fig.3 Response surface plot for rehydration ratio during thin layer drying of fenugreek leaves a $50-70^{\circ} \mathrm{C}$ and $0.4-0.8 \mathrm{~g} / \mathrm{cm}^{3}$ loading density

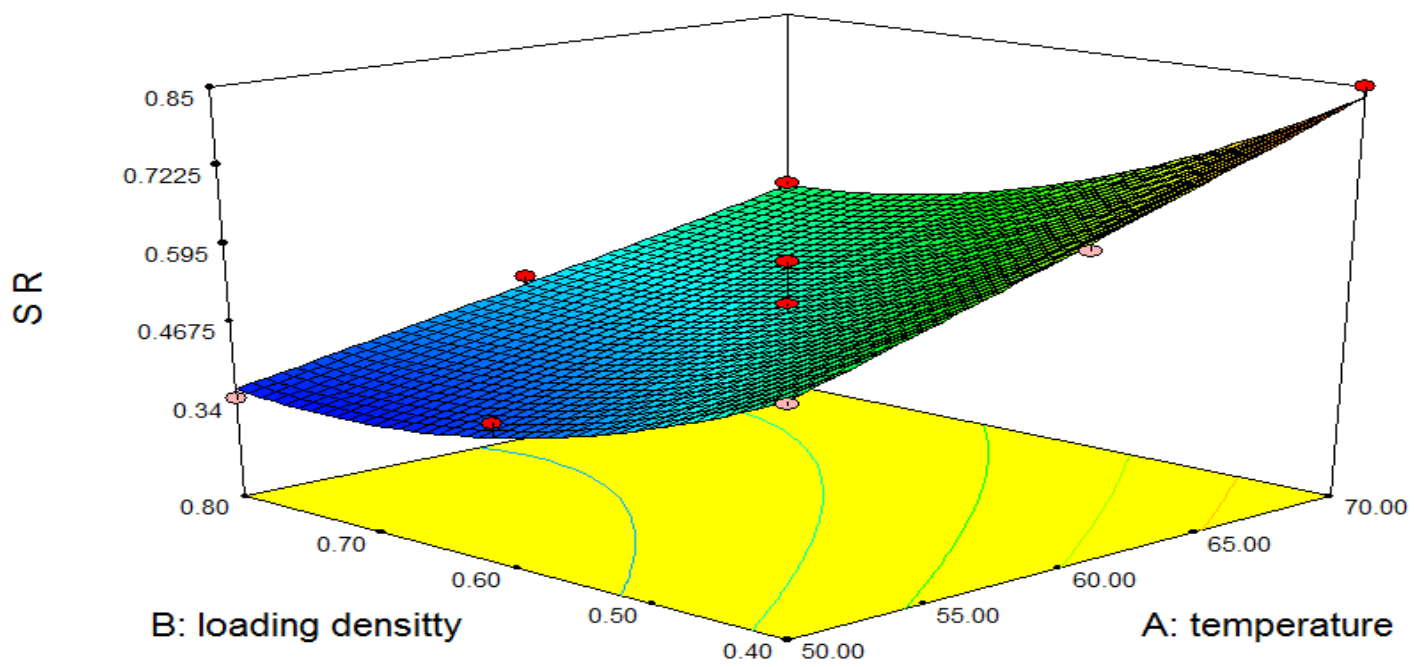


Fig.4 Response surface plot for shrinkage ratio during thin layer drying of fenugreek leaves at 50 $-70^{\circ} \mathrm{C}$ and $0.4-0.8 \mathrm{~g} / \mathrm{cm}^{3}$ loading density

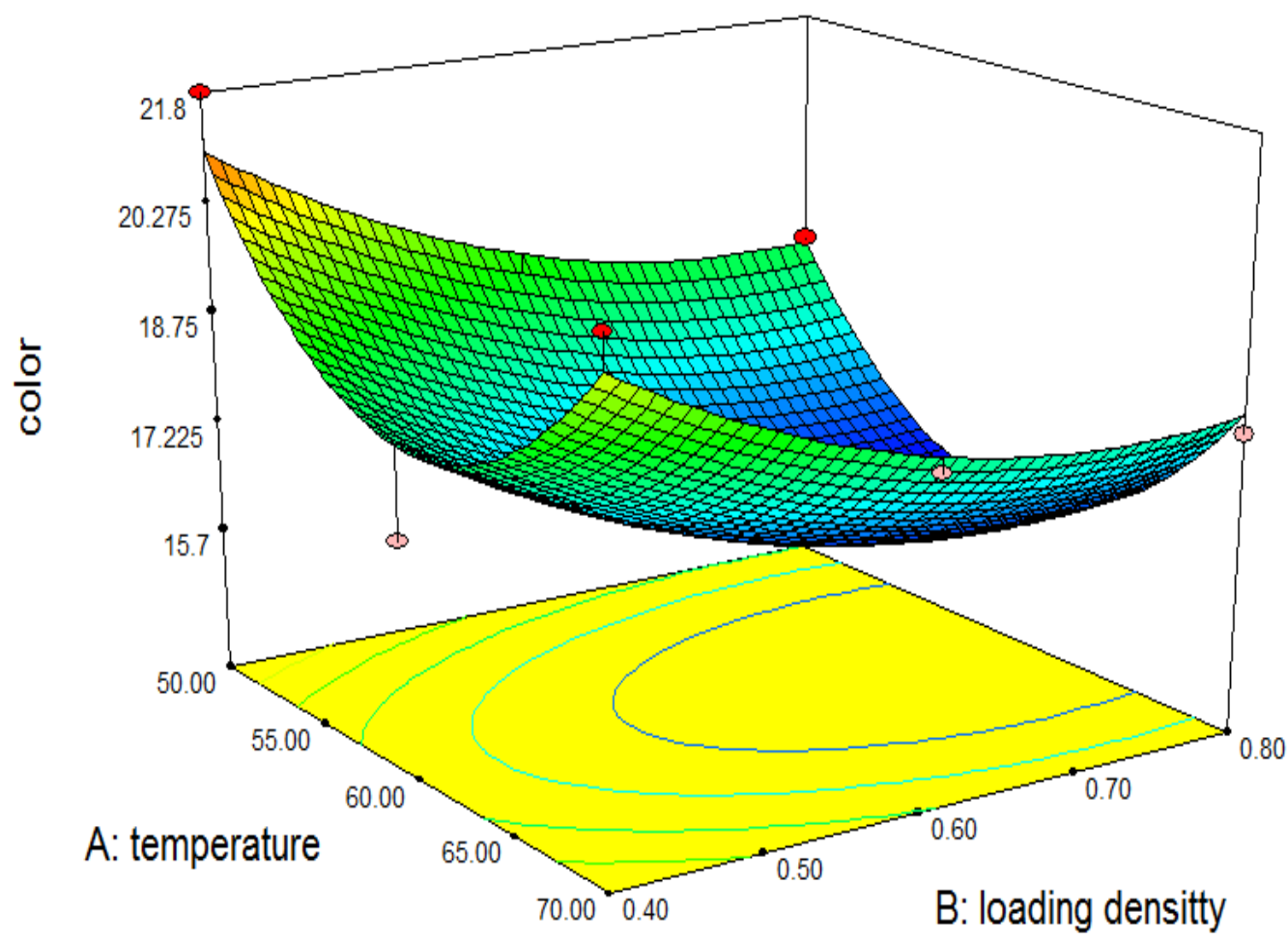

Fig.5 Response surface plot for color during thin layer drying of fenugreek leaves at $50-70^{\circ} \mathrm{C}$ and $0.4-0.8 \mathrm{~g} / \mathrm{cm}^{3}$ loading density

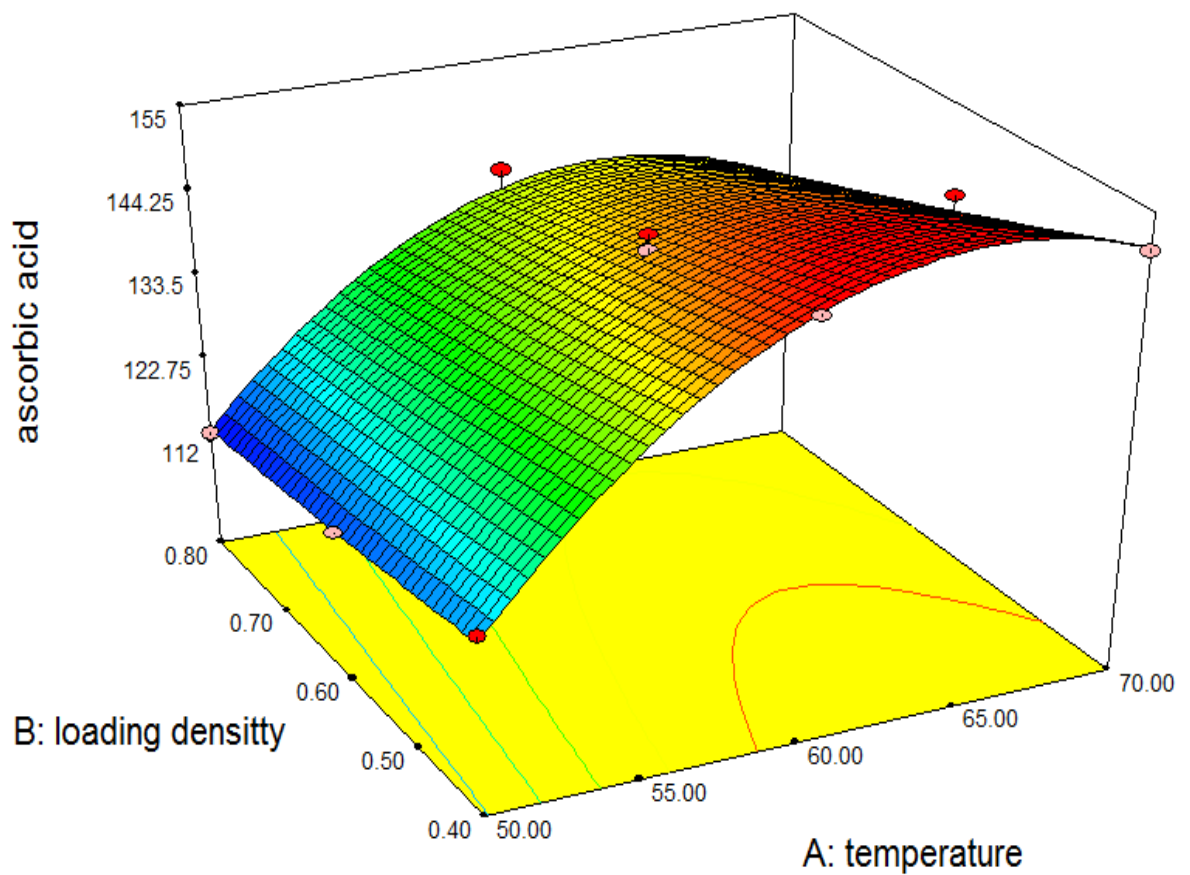


Fig.6 Response surface plot for ascorbic acid during thin layer drying of fenugreek leaves at 50 $70^{\circ} \mathrm{C}$ and $0.4-0.8 \mathrm{~g} / \mathrm{cm}^{3}$ loading density

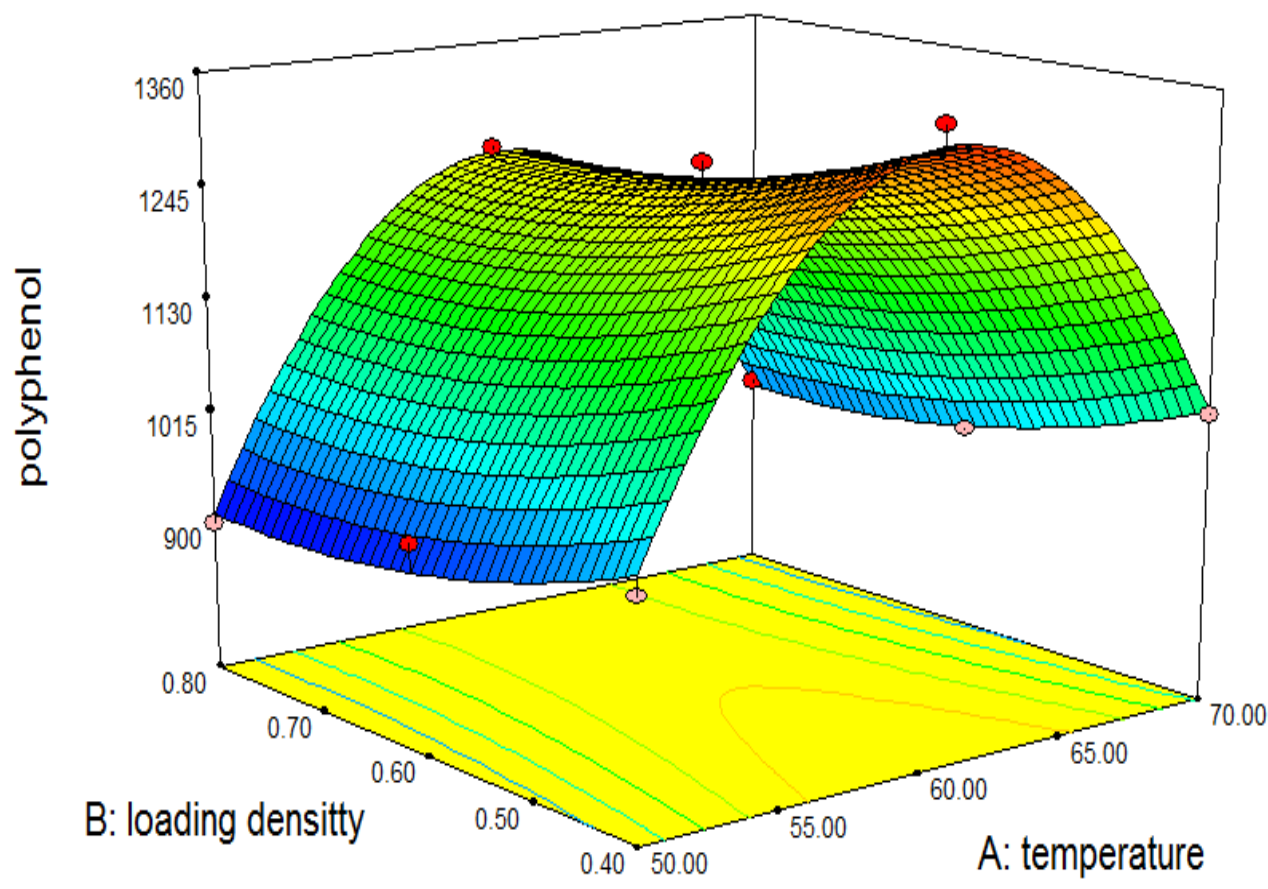

Fig.7 Response surface plot for polyphenols content during thin layer drying of fenugreek leaves at $50-70^{\circ} \mathrm{C}$ and $0.4-0.8 \mathrm{~g} / \mathrm{cm}^{3}$ loading density

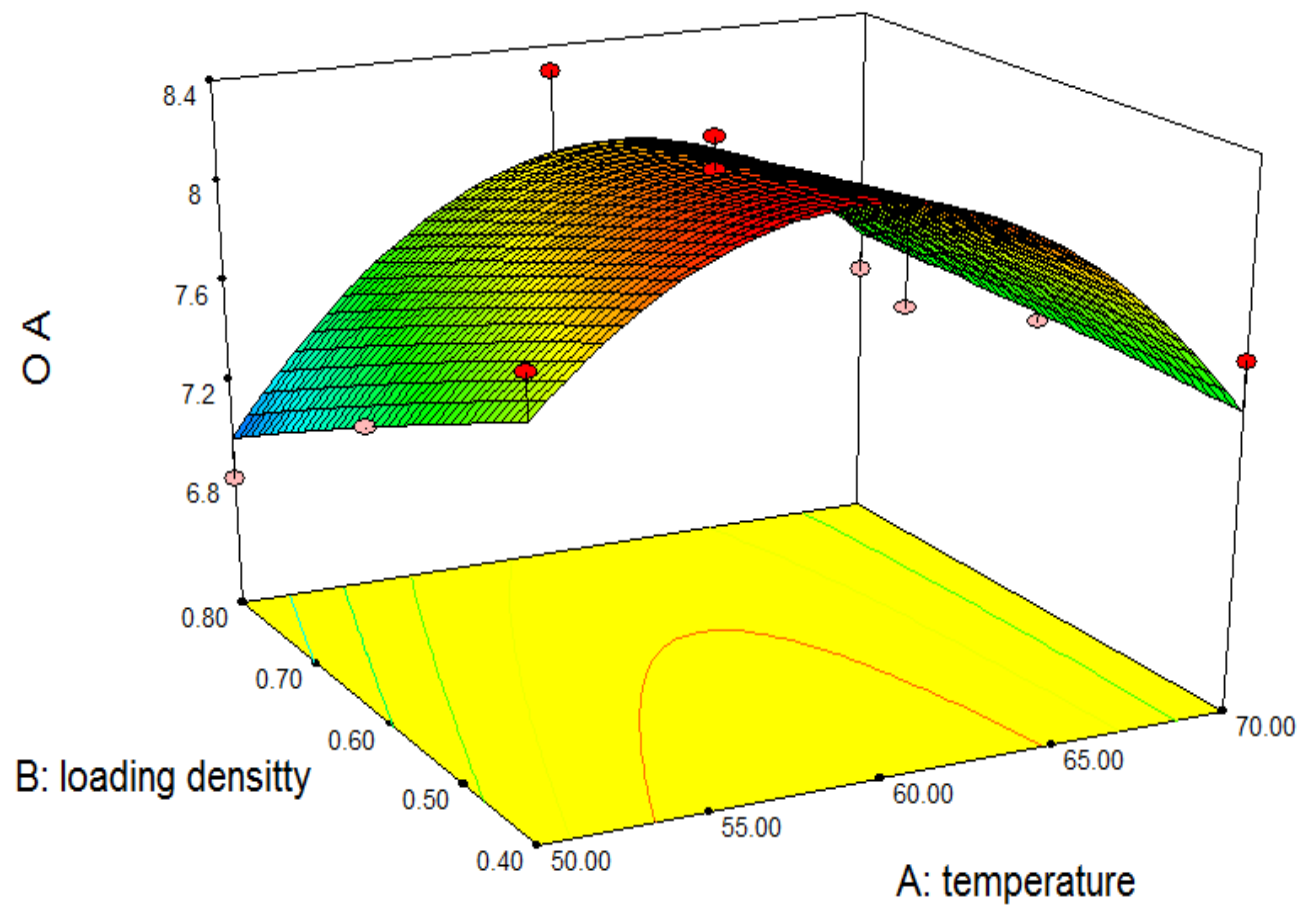


Fig.8 Response surface plot for overall acceptability during thin layer drying of fenugreek leaves at $50-70^{\circ} \mathrm{C}$ and $0.4-0.8 \mathrm{~g} / \mathrm{cm}^{3}$ loading density

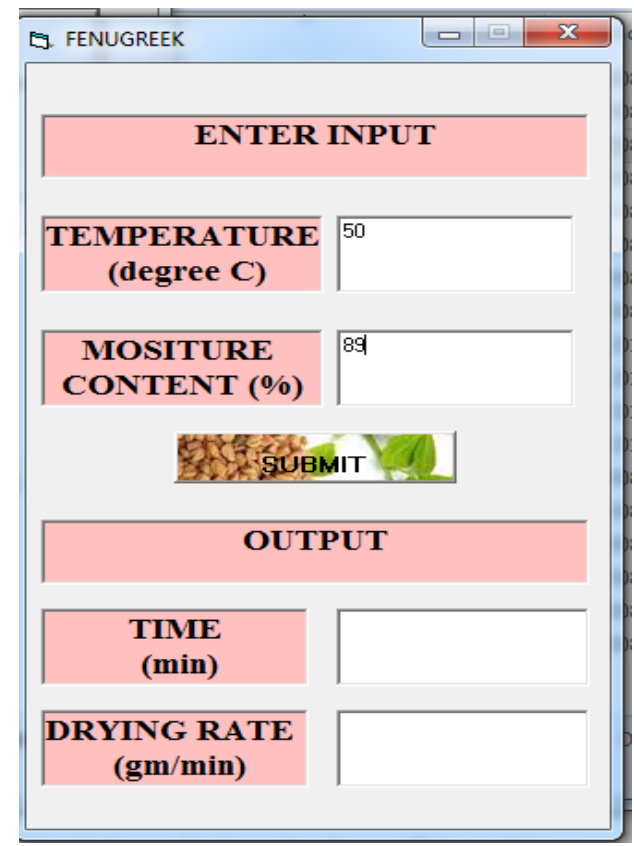

Fig.9 Input and output box of program

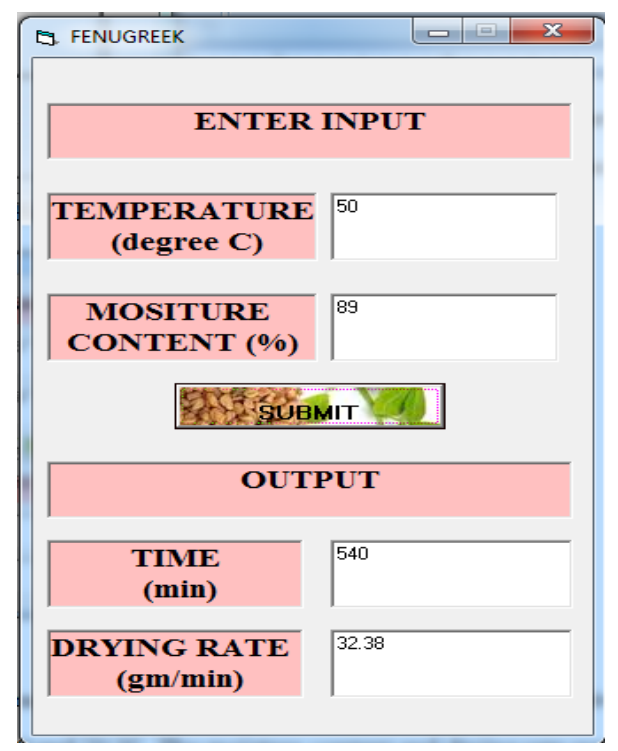

Table.1 Thin layer drying models considered

\begin{tabular}{|l|l|l|}
\hline S. No. & Model name & Model equation \\
\hline 1. & Newton & $M R=\exp (-\mathrm{kt})$ \\
\hline 2. & Henderson and Pabis & $M R=a \exp (-k t)$ \\
\hline 3. & Logarithmic & $M R=a \exp (-k t)+c$ \\
\hline
\end{tabular}


Table.2 Physico-chemical properties of fresh raw green mangoes

\begin{tabular}{|l|l|l|}
\hline S. No. & $\begin{array}{l}\text { Physicochemical } \\
\text { properties }\end{array}$ & Fenugreek \\
\hline 1. & Moisture Content $(\% \mathrm{wb})$ & $89.50 \pm 0.50$ \\
\hline 2. & Colour $\left(\mathrm{L}^{*}\right)$ & $56.60 \pm 0.07$ \\
\hline 3. & Ascorbic acid & $160.25 \mathrm{mg} / 100 \mathrm{~g}$ \\
\hline 4. & Polyphenols & $1600 \mathrm{mg} \mathrm{GAE} / 100 \mathrm{ml}$ \\
\hline
\end{tabular}

Table.3 ANOVA of total drying time ( $\mathrm{min}$ ) at different drying temperature

\begin{tabular}{|c|}
\hline Drying Temperature \\
\hline $50^{\circ} \mathrm{C}$ \\
\hline $60^{\circ} \mathrm{C}$ \\
${70^{\circ} \mathrm{c}}^{\circ}-60-50^{\circ} \mathrm{c}$ \\
\hline
\end{tabular}

\begin{tabular}{|c|}
\hline Drying time (min) \\
\hline $540 \pm 10.00^{\mathrm{a}}$ \\
\hline $330 \pm 6.00^{\mathrm{b}}$ \\
$330 \pm 9.16^{\mathrm{b}}$ \\
\hline $300 \pm 12.00^{\mathrm{c}}$ \\
\hline
\end{tabular}

All data are the mean \pm SD of duplicate readings. Mean \pm SD for followed by same letters in the same columns are not significantly different $(\mathrm{p} \leq 0.05)$.

Table.4 Parameters of various drying models of fenugreek leaves and related statistical indicators

\begin{tabular}{|c|c|c|c|c|c|c|c|}
\hline \multicolumn{8}{|c|}{ Fenugreek } \\
\hline \multirow[t]{2}{*}{ Drying Temperature } & \multicolumn{7}{|c|}{ Newton Model } \\
\hline & $\mathrm{R}^{2}$ & $\mathrm{Chi}^{2}$ & MBE & RMSE & \multicolumn{3}{|c|}{$\mathrm{k}$} \\
\hline $50^{\circ} \mathrm{C}$ & 0.979 & 0.0027 & -0.0102 & 0.0012 & \multicolumn{3}{|c|}{0.006} \\
\hline $60^{\circ} \mathrm{C}$ & 0.987 & 0.0014 & -0.0097 & 0.0006 & \multicolumn{3}{|c|}{0.012} \\
\hline $70^{\circ} \mathrm{C}$ & 0.995 & 0.0008 & -0.0093 & 0.0004 & \multicolumn{3}{|c|}{0.013} \\
\hline Drying Temperature & \multicolumn{7}{|c|}{ Henderson and Pabis Model } \\
\hline & $\mathrm{R}^{2}$ & $\mathrm{Chi}^{2}$ & MBE & RMSE & \multicolumn{2}{|c|}{$\mathrm{k}$} & $\mathrm{a}$ \\
\hline $50^{\circ} \mathrm{C}$ & 0.982 & 0.0023 & -0.0142 & 0.0009 & \multicolumn{2}{|c|}{0.006} & 1.048 \\
\hline $60^{\circ} \mathrm{C}$ & 0.988 & 0.0013 & -0.0114 & 0.0005 & \multicolumn{2}{|c|}{0.012} & 1.039 \\
\hline $7^{\circ} \mathrm{C}$ & 0.995 & 0.0010 & -0.0110 & 0.0003 & \multicolumn{2}{|c|}{0.013} & 1.013 \\
\hline Drying Temperature & \multicolumn{7}{|c|}{ Logarithmic Model } \\
\hline & $\mathrm{R}^{2}$ & $\mathrm{Chi}^{2}$ & MBE & RMSE & $\mathrm{k}$ & a & $\mathrm{c}$ \\
\hline $50^{\circ} \mathrm{C}$ & 0.994 & 0.0007 & 0.0052 & 0.0003 & 0.005 & 1.165 & -0.142 \\
\hline $60^{\circ} \mathrm{C}$ & 0.995 & 0.0005 & -0.0054 & 0.0002 & 0.011 & 1.075 & -0.051 \\
\hline $7^{\circ} \mathrm{C}$ & 0.998 & 0.0006 & -0.0038 & 0.0002 & 0.012 & 1.036 & -0.027 \\
\hline
\end{tabular}


Table.5 Effective moisture diffusivity $\left(\mathrm{m}^{2} / \mathrm{sec}\right)$ for drying of Fenugreek

\begin{tabular}{|l|l|}
\hline Temperature $\left({ }^{0} \mathrm{C}\right)$ \\
\hline $50^{\circ} \mathrm{C}$ \\
\hline $60^{\circ} \mathrm{C}$ \\
\hline $7^{\circ} \mathrm{C}$ \\
\hline
\end{tabular}

\begin{tabular}{|l|l|}
\hline & \\
\hline Eenugreek & \multicolumn{1}{|l|}{$\mathrm{R}^{2}$} \\
\hline $3.84 \times 10^{-10}$ & 0.996 \\
\hline $7.80 \times 10^{-10}$ & 0.997 \\
\hline $7.99 \times 10^{-10}$ & 0.992 \\
\hline
\end{tabular}

Table.6 Experimental data of drying of fenugreek slices for response surface analysis by mechanical drying

\begin{tabular}{|c|c|c|c|c|c|c|c|}
\hline $\begin{array}{c}\text { Temp. } \\
\left(\mathbf{(}^{\mathbf{C}}\right)\end{array}$ & $\begin{array}{c}\text { Loading } \\
\text { density }\left(\mathbf{g} / \mathbf{c m}^{\mathbf{3}}\right)\end{array}$ & $\mathbf{R} \mathbf{R}$ & $\mathbf{S ~ R}$ & $\begin{array}{c}\text { Color } \\
(\boldsymbol{\Delta} \mathbf{E})\end{array}$ & $\begin{array}{c}\text { Ascorbic acid } \\
(\mathbf{m g} / \mathbf{1 0 0 g})\end{array}$ & $\begin{array}{c}\text { Polyphenols } \\
(\mathbf{m g} / \mathbf{1 0 0 g}) \mathbf{G A E}\end{array}$ & O A \\
\hline $\mathbf{7 0}$ & 0.6 & 4.36 & 0.60 & 18.15 & 143.93 & 960.00 & 7.44 \\
\hline $\mathbf{6 0}$ & 0.8 & 4.39 & 0.46 & 15.99 & 140.80 & 1250.00 & 8.30 \\
\hline $\mathbf{5 0}$ & 0.4 & 3.63 & 0.53 & 21.79 & 120.45 & 980.00 & 7.98 \\
\hline $\mathbf{6 0}$ & 0.6 & 4.17 & 0.57 & 16.41 & 145.70 & 1230.00 & 8.32 \\
\hline $\mathbf{7 0}$ & 0.8 & 4.49 & 0.55 & 17.84 & 131.60 & 950.00 & 7.32 \\
\hline $\mathbf{6 0}$ & 0.6 & 4.28 & 0.41 & 16.13 & 141.27 & 1280.00 & 8.20 \\
\hline $\mathbf{6 0}$ & 0.4 & 4.09 & 0.67 & 16.84 & 149.99 & 1360.00 & 8.02 \\
\hline $\mathbf{7 0}$ & 0.4 & 4.27 & 0.85 & 20.69 & 150.40 & 1040.00 & 7.64 \\
\hline $\mathbf{5 0}$ & 0.8 & 4.24 & 0.34 & 18.50 & 112.80 & 900.00 & 6.80 \\
\hline $\mathbf{6 0}$ & 0.6 & 4.01 & 0.50 & 17.01 & 143.60 & 1250.00 & 8.10 \\
\hline $\mathbf{5 0}$ & 0.6 & 3.81 & 0.40 & 18.06 & 115.82 & 952.00 & 7.40 \\
\hline
\end{tabular}

Table.7 Optimum values of process parameters and responses of fenugreek

\begin{tabular}{|c|c|c|c|c|c|}
\hline Process parameters & Goal & $\begin{array}{c}\text { Lower } \\
\text { limit }\end{array}$ & $\begin{array}{c}\text { Upper } \\
\text { limit }\end{array}$ & Importance & $\begin{array}{c}\text { Optimization } \\
\text { level }\end{array}$ \\
\hline A: Temperature $\left({ }^{0} \mathrm{C}\right)$ & is in range & 50 & 70 & 3 & 61.28 \\
\hline B: loading density $\left(\mathrm{g} / \mathrm{cm}^{3}\right)$ & is in range & 0.4 & 0.8 & 3 & 0.8 \\
\hline Responses & & & & & predicted value \\
\hline Rehydration ratio & Maximize & 3.63 & 4.49 & 3 & 4.44 \\
\hline Shrinkage ratio & Minimize & 0.34 & 0.85 & 3 & 0.46 \\
\hline Color $(\Delta \mathrm{E})$ & Minimize & 15.99 & 21.79 & 3 & 15.80 \\
\hline Ascorbic acid & Maximize & 112.8 & 150.4 & 3 & 139.56 \\
\hline Polyphenols content & Maximize & 900 & 1360 & 3 & 1242.60 \\
\hline Overall acceptability & Maximize & 6.8 & 8.32 & 3 & 7.99 \\
\hline
\end{tabular}

\section{Shrinkage ratio}

The shrinkage ratio (SR) of tray dried fenugreek leaves varied in the range of 0.34 to 0.85 . The minimum SR (0.85) was found for $0.4 \mathrm{~g} / \mathrm{cm}^{3}$ loading density sample dried at 70 ${ }^{\circ} \mathrm{C}$ temperature.
At a constant temperature $\left(60{ }^{\circ} \mathrm{C}\right)$, the SR decreased $(0.67-0.46)$ with increasing loading density from 0.4 to $0.8 \mathrm{~g} / \mathrm{cm}^{3}$ (Fig. 4). The increase in drying temperature caused gradual decrease in shrinkage ratio (Leuicki and Jakubczyk, 2004). 
The value of $r$ squared 0.9272 . Final equation predicting SR as affected by temperature and loading density is given below:

Shrinkage ratio: $+0.40553+0.015048 *$ temperature-1.84254* loading densitty$0.013750 *$ temperature * loading density + $4.47368 \mathrm{E}-005^{*}$ temperature $2+1.73684^{*}$ loading density 2

\section{Color}

The color change of tray dried fenugreek leaves varied in the range of 15.99 to 21.79. The minimum change in color (15.99) was found for $0.8 \mathrm{~g} / \mathrm{cm}^{3}$ loading density sample dried at $60{ }^{\circ} \mathrm{C}$ temperature.

The effect of temperature and loading density on color of fenugreek are presented in Table 6 and the trend is shown in Figure 5. At a constant loading density $\left(0.4 \mathrm{~g} / \mathrm{cm}^{3}\right)$ change in color ( $\mathrm{L}$ value, a value, $\mathrm{b}$ value) increased (20.69- 21.79) by decreasing temperature from $70^{\circ}-50^{\circ} \mathrm{C}$. According to previous studies the dark green color afforded in drying of fenugreek as compare to fresh fenugreek leaves (Naidu et al., 2012).

Final equation predicting color as affected by temperature and loading density $\mathrm{g} / \mathrm{cm}^{3}$ is given below:

Color $(\mathrm{L}$ value $)=+119.871-3.04157^{*}$ temperature-32.94342 *loading density + $0.055000 *$ *emperature*loading density+ $0.024839 *$ temperature $^{2}+19.84868 *$ loading density $^{2}$

\section{Ascorbic acid}

The ascorbic acid content of fresh fenugreek slices was $160.25 \mathrm{mg} / 100 \mathrm{~g}$. After tray drying reduction in ascorbic acid was observed. Drying air temperature had major effect on ascorbic acid content. As shown in Figure 6 the minimum reduction of ascorbic acid observed at $70^{\circ} \mathrm{C}$ at $0.4 \mathrm{~g} / \mathrm{cm}^{3}$ loading density was $6.39 \%$. At constant temperature $70^{\circ} \mathrm{C}$ ascorbic acid values was decreased from 150.4 to 131.6 as loading density increased from 0.4 to $0.8 \mathrm{~g} / \mathrm{cm}^{3}$ with increased drying time.

The maximum ascorbic acid loss of 112.8 $\mathrm{mg} / 100 \mathrm{~g}$ was detected in the samples dried at $50^{\circ} \mathrm{C}$ and with $0.8 \mathrm{~g} / \mathrm{cm}^{3}$ loading density (Table 6). Similar results have been reported in Naidu et al., (2012) studies.

The $\mathrm{R}$ squared value was 0.985. Final equation predicting ascorbic acid as affected by temperature and thickness is given below:

Ascorbic $\quad$ acid $=\quad-509.06237+20.34841 *$ temperature+44.10395* loading density* 1.39375 temperature * loading density$0.15193 *$ temperature $2+8.18421^{*}$ loading density 2

\section{Polyphenol content}

The polyphenols content was about $1400 \mathrm{mg}$ GAE/100 $\mathrm{g}$ in fresh fenugreek slices. The value of polyphenols content decreased on drying at constant temperature with different loading density.

The value of polyphenols content was varied from 950 - $1360 \mathrm{mg}$ GAE/100 g. The maximum polyphenols content of $1360 \mathrm{mg}$ $\mathrm{GAE} / 100 \mathrm{~g}$ was found at $60^{\circ} \mathrm{C}$ with loading density $0.4 \mathrm{~g} / \mathrm{cm}^{3}$. The trend of polyphenols content presented by Figure 7 and values shown in (Table 6). It shows that minimum degradation $2.85 \%$ was found at $60^{\circ} \mathrm{C}$.

Final equation predicting ascorbic acid as affected by temperature and loading density is given below:

Polyphenols $=-9951.52632+\quad 384.88509 *$ 
temperature-1074.12281*loading density$1.25000 *$ temperature * loading density$3.18474 *$ temperature $2+763.15789^{*}$ loading density2.

\section{Overall acceptability}

The OA of tray dried fenugreek varied in the range of 7.32 to 8.32 . The maximum $\mathrm{OA}$ (8.32) was found at $60{ }^{\circ} \mathrm{C}$ temperature, and $0.6 \mathrm{~g} / \mathrm{cm}^{3}$ loading density (Table 6 ).

The effect of temperature and loading density on OA of fenugreek slices trend is shown in Figure 8. At a constant loading density (0.4) Overall Acceptability decreased (7.98 and 7.64) with increasing temperature from 50 and $70^{\circ} \mathrm{C}$.

The value of adjusted $\mathrm{R}$ square was 0.848 . Final equation predicting $\mathrm{OA}$ as affected by temperature and thickness is given below:

$\mathrm{OA}=+14.82579+0.84422 *$ temperature$7.04035^{*}$ loading density $+0.10750 *$ temperature * loading density-7.54211E-003* temperature2-0.35526* loading density2

\section{Optimized results}

The optimum operating conditions for drying of fenugreek with temperature and loading density was $61.28^{\circ} \mathrm{C}$ and $0.8 \mathrm{~g} / \mathrm{cm}^{3}$ as shown in Table 7.

\section{Computer based program}

Change in product weight at different temperature was observed manually at $30 \mathrm{~min}$ interval. Then excel sheets were prepared for calculation of moisture content, drying rate and drying time and other drying values. With help of visual basic language program was developed; it gives values based on data feed in the program which was calculated from the drying process.
Drying time decreased with increase in temperature. At particular drying temperature with change in moisture content the drying time and rate also changed. So, air drying temperature and moisture content ( $\mathrm{wb} \%)$ was taken as input sources. By submitting the input values the output of drying time (min) and drying rate will be obtained as shown in Figure 9. This automated program helps in reduction of human intervention. There is no need to repeat whole process for different temperature. The results give how much time will be taken for drying of fenugreek when moisture content varied from $88-91 \%$.

The drying characteristics of fenugreek leaves were studied in convective tray dryer at the drying air temperature of 50,60 and $70^{\circ} \mathrm{C}$. The moisture content and drying rate were affected by drying air temperature. Increase in drying air temperature caused decrease in drying time and an increase in drying rate. The results of the analysis of variance showed significant $(p<0.05)$ effect of air temperature. Logarithmic drying model gave higher value for coefficient of determination and lower values for the chi square, mean bias error and root mean square error.

The effective diffusivity and rehydration ratio increased with the increasing drying air temperature. Air drying temperature $60{ }^{0} \mathrm{C}$ maintained original color of fenugreek leaves with minimum change in color. Maximum retention of ascorbic acid and polyphenols content and minimum shrinkage ratio was observed at higher temperature. However, optimum tray drying $61{ }^{0} \mathrm{C}$ with $0.8 \mathrm{~g} / \mathrm{cm}^{3}$ loading density shows maximum retention of ascorbic acid, polyphenols content, rehydration ratio with minimum change in color and shrinkage ratio. Computer language 'visual basic' based program provide automation by giving output of total drying time (min) and drying rate $(\% \mathrm{db} / \mathrm{min})$ at different drying temperature and moisture content $\%$ (wb). 


\section{References}

Akpinar, E. K., Bicer, Y., and Yildiz, C. (2003). Thin layer drying of red pepper. Journal of Food Engineering.59, 99-104.

Akpinar, K. E. (2006). Determination of suitable thin layer drying curve model for some vegetables and fruits. Journal of Food Engineerin. 73(1), 75-84.

AOAC, (2006). Official methods 967.21 Ascorbic acid in vitamin preparations and juices: 2, 6 - Dichloroindophenol titrimetric method. Official methods of Analysis of the Association of Official Analytical Chemists (accessed on 13 April, 2014).

Dadali, G., Apar, D. K., and Ozbek, B. (2007). Estimation of effective moisture diffusivity of okra for microwave drying. Drying Technology.25, 1445-1450.

Diamante, L. M., and Munro, P. A. (1993). Mathematical modeling of the thin layer solar drying of sweet potato slices. Solar Energy.51, 271- 276

Dincer, I. and Dost, S. (1995). An analytical model for moisture diffusion in solid objects during drying. Drying Technology.13, 425435

Doymaz, I. (2006). Thin layer drying behavior of mint leaves. Journal of Food Engineering. 74, 370-375.

Doymaz, I. (2007). Air drying characteristics of tomatoes. Journal of Food Engineering.78, 1291-1297.

Galvez, V. A., Mondaca, L. R., Sainz, B. C., Fito, P. and Andres, A. (2008). Effect of air drying temperature on the quality of rehydrated dried red bell pepper (var. Lamuyo). Journal of Food Engineering.85, 42-50.

Gomez, K. A. and Gomez, A. A. (1983). Statistical Procedure for Agriculture Research. John Wiley and sons, New York, pp, 356-422.

Gornicki, K. and Kaleta, A. (2007). Drying curve modeling of blanched carrot cubes under natural convection condition. Journal of Food Engineering. 82, 160-170.

Gupta, S., Cox, S. and Ghannam, A. N. (2011). Effect of different drying temperature on the moisture and phytochemical constituents of edible Irish brown seaweed. LebensmittelWissenschaft und-Technologie Food Science and Technology. 30, 1-7.

Kingsly, R. P., Goyal, R. K., Manikantan, M. R. and Ilyas, S. M. (2007). Effect of pretreatments and drying air temperature on drying behaviour of peach slice. Journal of Food Science and Technology.42, 65-69.

Leuicki, P. P. and Jakubczyk, E. (2004). Effect of hot air temperature on mechanical properties of dried apples. Journal of Food Engineering.64, 307-314.

Madamba, P. S. (2003). Thin layer drying models for osmotically pre-dried young coconut. Drying Technology.21, 1759-80.

Maskan A, Kaya S and Maskan M (2002) Hot air and sun drying of grape leather pestil. Journal of Food Engineering.54, 81-88.

Meisami-asl, E., Rafiee, S., Keyhani, A. and Tabatabaeefar, A. (2010). Determination of suitable thin layer drying curve model for apple slices (variety -golab). Journal of Plant Omics.3(3), 103-108.

Mohsenin, N. N. (1986). Physical properties of plant and animal materials. Pp. 891-892. Gordon and Beach Science Publication, New York.

Naidu, M. M., Khanum, H., Sulochanamma, G., Sowbhagya, H. B., Hebbar, U. H., Prakash, M. and Srinivas, P. (2012). Effect of drying methods on the quality characteristics of fenugreek (Trigonella foenum - graecum) greens. Drying Technology.30, $808-816$.

Negi, S. P., and Roy, K. S. (2001). Effect of drying conditions on quality of green leaves during long term storage. International Journal of Food Research. 34, 283-287

Pala, M., Mahmutoglu, T., and Saygi, B. (1996). Effects of pretreatments on the quality of open air and solar dried products. Journal of Food Research.40, 137-141

Pande, V. K., Sonune, A.V., andPhilip, S. K. (2000). Solar drying of coriander and methi leaves. Journal of Food Science and Technology. 37(6), 592-595.

Pokharkar, S. M. and Parsad, S. (2002). Air drying behaviour of osmotically dehydrated pineapple. Journal of Food Science and Technology.39, 384-387.

Rana, R. K. and Pandey, S. K. (2007). Processing quality potatoes in India: An estimate of industry's demand. Proc Food Ind 10, 26-35.

Ranganna, S. (1986). Handbook of analysis and 
quality control for fruits and vegetable products. $2^{\text {nd }}$ edition, pp, 171-74. Tata McGraw Hill publishing company Ltd. New Delhi, India

Rayaguru, K. and Routray, W. (2012). Mathematical modeling of thin layer drying kinetics of stone apple slices. International Journal of Food Research. 19(4), 1503-1510.

Sacilik, K., Elicin, A. K., and Unal, G. (2006). Drying kinetics of Uryani plum in a convective hot-air dryer. Journal of Food Engineering.76, 362-68.

Sarsavadia, P. N., Sawhney, R. L., Pangavhane, D. R., and Singh, S. P.(1999). Drying behaviour of brined onion slices. Journal of Food Engineering.40, 219-226.

Senadeera, W., Bhandari, B. R., Young, G., and Wijesinghe, B. (2003). Influence of shapes of selected vegetable materials on drying kinetics during fluidized bed drying. Journal of Food Engineering. 58, 277-283.
Singleton, V. L., Orthofer, R., and Samuela, R. R. M. (1999). Analysis of total phenols and other Oxidation substrate and antioxidants by means of Folin - Ciocalteau Reagent. Methods in Enzymology. 209, 152 -187.

Wang, Y., Li, D., Wang, L. J., Chiu, Y. L., Chen, X. D., Mao, Z. H. and Song, C. F. (2007). Optimization of extrusion of flaxseeds for in vitro protein digestibility analysis using response surface methodology. Journal of Food Engineering. 85, 59-64.

Yaldiz, O., Ertekin, C. and Uzun, H. I. (2001). Mathematical modeling of thin layer solar drying of sultana grapes. Energy Oxford.26, 457- 465

Zogzas, N. P., Maroulis, Z. B., and Kouris, M. D. (1996). Moisture diffusivity data compilation in food stuffs. Drying Technology.14, 2225 2253.

\section{How to cite this article:}

Ramandeep Kaur, Mahesh Kumar, O.P. Gupta, Sukreeti Sharma and Satish Kumar. 2018. Drying Characteristics of Fenugreek and Its Computer Simulation for Automatic Operation. Int.J.Curr.Microbiol.App.Sci. 7(03): 3275-3291. doi: https://doi.org/10.20546/ijcmas.2018.703.378 